\title{
Stimulation of children with congenital Zika syndrome at home: challenges for the caregivers
}

How to cite this article: Junqueira CCS, Leôncio ABA, Vaz EMC, Santos NCCB, Collet N, Reichert APS. Stimulation of children with congenital Zika syndrome at home: challenges for the caregivers. Rev Gaúcha Enferm. 2020;41:e20190247. doi: https://doi. org/10.1590/1983-1447.2020.20190247
Universidade Federal da Paraíba (UFPB), Centro de Ciências da Saúde, Mestrado Profissional em Saúde da Família. João Pessoa, Paraíba, Brasil.

b Universidade Federal da Paraíba (UFPB), Centro de Ciências da Saúde, Departamento de Enfermagem em Saúde Coletiva. João Pessoa, Paraíba, Brasil.

Universidade Federal de Campina Grande (UFCG), Centro de Educação e Saúde. Campina Grande, Paraíba, Brasil.
Estimulação de crianças com síndrome congênita pelo Zika vírus no domicílio: desafios do cuidador

Estímulo de niños con síndrome congénita por el Zika vírus en la residencia: desafíos del cuidador

\section{Cora Coralina dos Santos Junqueira ${ }^{a}$ \\ Alane Barreto de Almeida Leônciob Elenice Maria Cecchetti Vaz ${ }^{b}$ Nathanielly Cristina Carvalho de Brito Santos ${ }^{c}$ Neusa Collet ${ }^{\mathrm{a}, \mathrm{b}}$ Altamira Pereira da Silva Reichert ${ }^{a, b}$}

ABSTRACT

Objective: To identify the challenges faced by caregivers regarding the stimulation of the development of children with congenital Zika syndrome at home.

Method: A qualitative study was carried out with ten caregivers of children with the syndrome and five health professionals who work in a specialized service of reference for children/adolescents with disabilities in a city in Pernambuco, Brazil. Data collection took place between November 2018 and March 2019 through a semi-structured interview, and the data were interpreted using thematic analysis.

Results: The challenges faced by caregivers are permeated by fear, insecurity and lack of support for the realization of the stimulatory activities at home. Practitioners acknowledge the situation but emphasize the importance of continuing the stimulatory activities to preserve the capabilities of these children.

Conclusions: It is necessary to sensitize health teams to support families regarding the challenges faced and provide full time care for the child with Zika syndrome in order to achieve maximum development.

Keywords: Child health. Zika virus. Developmental disabilities. Professional-family relations. Pediatric nursing.

RESUMO

Objetivo: Identificar os desafios enfrentados por cuidadores quanto ao estímulo do desenvolvimento de crianças com Síndrome Congênita pelo Zika vírus no domicílio.

Método: Estudo qualitativo, realizado com dez cuidadores de crianças com a síndrome e cinco profissionais de saúde que atuam num serviço especializado de referência à criança/adolescente com deficiência de um município pernambucano. A coleta ocorreu entre novembro/2018 e março/2019 através de entrevista semiestruturada, e os dados interpretados pela análise temática.

Resultados: Os desafios enfrentados pelos cuidadores são permeados pelo medo, insegurança e falta de apoio para a realização do estímulo no domicílio. Os profissionais reconhecem a situação, contudo, enfatizam a importância da continuidade do estímulo para preservar as capacidades destas crianças.

Conclusões: Torna-se necessário sensibilizar as equipes de saúde para apoiar as famílias nos desafios, e para o cuidado integral à criança com a Síndrome do Zika, a fim de alcançar o máximo possível o seu desenvolvimento.

Palavras-chave: Saúde da criança. Zika vírus. Deficiências do desenvolvimento. Relações profissional-família. Enfermagem pediátrica.

RESUMEN

Objetivo: Identificar los desafíos enfrentados por cuidadores en cuanto al estímulo del desarrollo de niños con Síndrome Congénita por el Zika vírus en la residencia.

Método: Estudio calitativo, realizado con diez cuidadores de niños con la síndrome y cinco profesionales de salud que actúan en un servicio especializado de referencia al niño/adolescente con deficiencia, en un municipio pernambucano. La recogida de datos ocurrió entre noviembre/2018 y marzo/2019 a través de entrevista semiestructurada, y los datos interpretados por el análisis temático.

Resultados: Los desafíos enfrentados por los cuidadores está permeado por el miedo, inseguridad y falta de apoyo para la realización del estímulo en la residencia. Los profesionales reconocen la situación, con todo, enfatizan la importancia de la continuidad de dicho estímulo para preservar las capacidades de estos niños.

Conclusiones: Se hace necesario sensibilizar los equipos de salud para apoyar las familias en los desafíos, y para el cuidado integral al niño con la Síndrome del Zika, con vistas a alcanzar el máximo posible su desarrollo.

Palabras clave: Salud del niño. Virus Zika. Discapacidades del desarrollo. Relaciones profesional-familia. Enfermería pediátrica. 


\section{口INTRODUCTION}

Zika virus surfaced abruptly in Brazil, leading public health into a situation of emergency due to its teratogenic power, especially since it causes microcephaly in the newborns of women affected by the virus, provoking not only clinical consequences, but also financial and social impacts to the families $^{(1)}$.

From October 2015 to January 2019,3,332 cases of microcephaly were confirmed, with alterations in the growth and development of the child. These cases were possibly associated to the Zika virus infection and to other infectious etiologies. The Brazilian northeast region stands out with the highest number of cases, and there, via clinical-radiologic and clinical-laboratory criteria,2,122 cases were identified ${ }^{(2)}$.

In addition to microcephaly, the most common alteration, other malformations and diffuse calcification of the brain were observed, including ventriculomegaly, optic nerve hypoplasia, macular atrophy, cataract, impaired hearing and visual functions, arthrogryposis, spasticity, hyperreflexia, irritability, tremors and convulsions, characterizing, as a result, a congenial syndrome - the Congenital Zika Syndrome $(C Z S)^{(3)}$.

The birth of a child with serious health problems, such as CZS, substantially changes the lives of the parents, who expected their child to be different from the child who was born. This unexpected event continues to have a great impact on the children affected, their families and communities, requiring changes in family routine and affecting intrapersonal and interpersonal relations, as well as daily lives, in their occupational, personal and social aspects, and requiring daily presence in health services ${ }^{(1,4)}$.

The family of a child who needs special care, as in the case of a chronic disease, needs information from professionals capable of reducing their uncertainties, preoccupations and stress when dealing with the care for the child, in addition to support from family members to deal with the disease of the child. Additionally, parents must find treatment strategies that can be balanced with their personal work lives and leisure(5).

In this context, the pediatric nurse stands out as a necessary actor to strengthen the social support network and give families the instruments to deal with the implications brought about by the disease, softening the suffering and diminishing the anguish and the doubts that arise with the deficiency, in addition to offering support for the self-care in the growth/development of the diseased child(5-6).

Literature indicates some of the challenges that the parents of children with CZS have to face, such as the fear and the insecurity in the performance of activities to stimulate the development, and their lack of knowledge with regards to the house care to be offered to their children. However, understanding the development of the children from their relations with their environment leads the family to practice this type of stimulatory activity more often and better, focusing on the potential of the child and on the reduction of regression that results from the advances achieved ${ }^{(7-8)}$.

To do so, parents and relatives must be encouraged and guided to become active subjects in the care of the children, stimulating them in the daily routine of the family environment and context. The family and social environment in which children grow is seen as the one with the most stimuli for them, since this is where they learn, where they live and spend most of their time, and it is where they are involved with their parents. Therefore, it is paramount for an effective stimulation of children with developmental delays ${ }^{(9)}$.

Considering the above, the following question emerged: What are the challenges faced by caregivers to stimulate children with the Congenial Zika Syndrome at home? To answer this question, this study aimed to identify the challenges faced by caregivers with regards to stimulating the development of children with Congenial Zika Syndrome at home.

\section{METHODS}

This article is an excerpt from a master's degree dissertation titled "Stimulation of the neuropsychomotor development of children with Congenial Zika Syndrome". It is an exploratory-descriptive research with a quantitative approach, carried out in a specialized service, a reference for the attention of children and adolescents with deficiencies, in a city in the state of Pernambuco (PE), Brazil, that attends children with CZS.

This institution aims at increasing the access of children below 18 years of age to health services and has 25 professionals. The service offers attention in the fields of psychiatry, dentistry, nutrition, ophthalmic tests (red reflex exam), in addition to physical therapy, speech therapy, and occupational therapy. These last ones, directed at children with CZS and other neuropsychomotor disorders, attend nearly 500 children a week.

This study counted on the participation of ten relatives who are the caregivers of children with the Congenial Zika Syndrome, and five professionals from the health service mentioned. Inclusion criteria for the caregivers included: being the main caregiver of the child with the syndrome, being 18 years old or older, being registered in a reference service in the city, and living in the city in which the research was carried out. The criterion for health professionals was: carrying out neuropsychomotor stimulatory activities 
for children with CZS in the referred service. Professionals who were on vacations or on leave during data collection were excluded, as were caregivers who did not go to the service for follow ups with the child in three consecutive scheduled dates.

Data collection took place from November 2018 to March 2019 through semi-structured interviews, whose audio was recorded in electronic devices and later transcribed for analysis. Initially, the caregivers were invited to participate, and the day and time were scheduled. Then, the main researcher interviewed them for a mean of 15 minutes each. This took place in a room other than the one in which the child was attended, respecting the privacy of the participant.

The interviews with the caregivers were directed by the guiding questions: How well are going the activities to stimulate the development of your child at home? Who takes part in this process? Are there any difficulties in carrying out these stimulatory activities? For the health professionals: How do you guide the caregivers of children with Congenial Zika Syndrome to carry out neuropsychomotor stimulatory activities at home? What are the challenges for health professionals once they realize that the neuropsychomotor stimulatory activities for a child with CZS are not being carried out at home? The study sought to include all actors involved in the attention to the stimulatory activities to aid the development of these children. Data collection was considered finished through the criterion of sufficiency, that is, when the number of interlocutors seemed enough to reflect the many dimensions of the object, which was verified through the repetition and complementarity of the information ${ }^{(1)}$.

A thematic analysis subsidized the interpretation of data and was developed in three stages: pre-analysis, which included the organization of the material collected after a repeated and exhaustive reading of the articles, which lead to an initial organization and thematic categorization of data taking into consideration the objectives of this study; exploration of the empirical material, which included its grouping in thematic cores; and final analysis, including the treatment and interpretation of the results found under the light of the pertinent literature(11).

The analysis of the empirical material led to the creation of a category called: Challenges for the caregivers of children with CZS with regards to home stimulation. From this category, two thematic cores emerged: Challenges faced by the caregivers to stimulate the children with Congenial Zika Syndrome and The continuity of care from the perspective of the health team.

The study was in accordance to all ethical precepts, being approved under protocol n. 3.426.153 and CAAE: 00452618.8.0000.5188. All participants signed the Free and
Informed Consent Form. To guarantee their anonymity, their statements were codified using the letters " $C$ "for caretakers and " $\mathrm{P}$ "for health professionals, then followed by a number corresponding to the chronological order in which the interviews were carried out: C1, [...] and P1, [...].

\section{RESULTS AND DISCUSSION}

Among the ten caretakers, nine were mothers and one was a grandmother, and they were from 19 to 43 years of age. As to educational level, the length of formal study varied from five to eighteen years. Eight mothers were in stable unions, one mother and the grandmother were single. Family income varied from $R \$ 600.00$ to $R \$ 4,200.00$ The ages of the children varied from 19 to 36 months. Six were male and four were female. Regarding stimulatory therapies, one of the children attended four health services, two of them attended three, three of them attended two, and four of them attended only one. All children participated in motor, visual, auditory, and language therapies, in addition to therapies for cognitive and behavioral abilities.

Five health professionals also participated in the study. They were all female and worked in the reference service, working directly with neuropsychomotor stimulation of children with CZS. They were a nutritionist, a visual physical therapist, a motor physical therapist, an occupational therapist, and a speech therapist. Four of them work in the service since its inception, two years ago. The other has been there for ten months. All of them had working experience (mean of 11.4 years) with children with neurological disorders.

\section{Challenges faced by the caregivers to stimulate the children with Congenial Zika Syndrome}

With the change in their daily lives provoked by the birth of a child with CZS, and dealing with a fragmented Healthcare Network (HN) that cannot attend to all the complex demands of care of the population of children with deficiencies, families must go to several health services in their search for attention and rehabilitation, a peregrination that becomes part of their routine and of the routine of the child.

Every day I go out with him [...] On Mondays, every fifteen days, we come here, on Tuesdays at service $C$, on Wednesday at service $D$, and Thursday at $E$, then, on Fridays, if the neurologist is there, we go, if she's not, we stay home (C5).

It stands out that the child with CZS has a delayed neuropsychomotor development, and there is no specific 
treatment for this condition. Therefore, they need a constant and longitudinal access to the treatment and rehabilitation offered by the Single Health System (SUS), such as physical therapy, occupational therapy, and speech therapy, throughout their entire lives ${ }^{(3)}$. It should also be noted that none of the participants decided to treat the child in the Primary Healthcare (PHC), showing that both the fragmentation and the low valorization of the specialized services are still a reality.

According to reports from some interviewees, this treatment routine occupies a great deal of their time. In addition, this daily care may significantly interfere in the adherence and participation of these women in the treatment of their children, resulting in prejudices to the clinical evolution of the deficient children ${ }^{(12)}$, such as those with CZS. This statement is corroborated by the discourse of a professional, when talking about the high number of therapies to which the child is submitted.

\section{[...] the mother takes the child to lots of places, I know she is a very careful mother [...] but it's too much stimuli, the child becomes irritated, aggressive. That is a result of the excess of therapies. [...] So, this expectation (that the child will develop fast) makes it so they (the mothers) still run after many treatments in many different places (P4).}

Regarding the number of stimulatory activities offered, it is important to understand the uniqueness of each situation, understanding the capabilities, the interest, and the possibilities of each child, as to offer them the adequate amount of stimulation, but without excess. The child must not be forced, nor exhausted, because in this relationship it is essential to know the needs of the child and the right amount required to supply those needs ${ }^{(9)}$. Therefore, professionals and caregivers must reach an understanding regarding the processes and modes of stimulation, respecting the uniqueness of each child in each stage of the therapy.

Data also reports that the complex routine of care requires exclusive dedication from these women, since they are the ones responsible for taking the children to the health services, and also for the general care of the child at home. In addition to the several roles they develop with regards to the child, they must carry out household chores and care for their other children ${ }^{(7)}$, generating exhaustion, which in turn can lead to lack of energy to stimulate the child with the syndrome at home.

Other than that (stimulating the child at home) there's the house, I take care of the house, I make lunch, I wash the clothes, I do other stuff, it's tiring [...] And then, when he sleeps, then I sleep too (C5).
It's difficult because I feel a bit tired, since I have to go with him to the doctor, the physical therapist, I have to be with him every minute of the day (C9).

Corroborating this aspect, literature(7,12) highlights that taking care of a child with a deficiency is a condition that may be permanent. The tiring work routine, associated to the demand of household chores, caring for the child, the husband and other children, these activities lead to physical overload, leaving these women stressed and tired.

This maternal overload is partly a result of the culture that has been historically stablished in our society, which restricts the women to the role of primary caregiver. Additionally, the connection between mother and child may also justify the main role of the mother in the act of caring for the child ${ }^{(6)}$. Therefore, the demands from the mother/ caregiver of a child with deficiencies are even higher, since it places the strength of the perspective of maternity as an integral activity, in addition to the demands imposed by the situation being experienced ${ }^{(4)}$. In this daily entanglement, the caregiver chooses a day to miss therapy, and the health team notices that she is exhausted, and the consequences that derive from this exhaustion.

Well, some of the mothers are depressive, they have to care for five children, to care for the special child and for the other four children [...] Some mothers do not accept the child with the deficiency [...] / notice that the mother is tired, and that she chooses the therapy that she won't go to this week, so she can rest [...] because there's therapy every day for the child (P5).

The adherence of the mothers to the care of the children with this chronic condition may be frail, considering the state of psychological disorder in which these women live, such as depression, in addition to the denial of having a child with a deficiency, which is not uncommon. The fact that they often do not follow guidance to continue care at home may be related to the non-acceptance of the diagnostic, to the financial conditions of the family, to the physical structure of the home environment, and to social and psychological aspects. Therefore, it is important for the professionals involved in the care for these children to know the daily lives of these families, in order to adopt health strategies that can improve not only the stimulatory activities of the child at home ${ }^{(12)}$, but also contemplate the needs of the caregiver.

Regarding the stimulation to the child at home, the mothers/grandmother report that, when they carry the activities out, they are, in most cases, the only ones responsible for doing so, since other people in the family do not effectively 
collaborate. Sharing the care and receiving support from other relatives is, however, essential to soften the burden.

I do (stimulate the child at home) and the father does it, when he has time, which is very rare, he works. [...] I take care of her in a way and another person that I let do it won't know how to do it right (C4).

At homel don't do it, because sometimes my husband is not there and I need someone to hold him [...] Some days I can't do the stimulation, it's too much [...] sometimes I forget. [...] The father helps me, he holds him, walks with him, when he's at home he stays with him while I do the other things (household chores) (C5).

My mother holds her when I need to do my things, but the stimulation I'm the one to do, or the father on Sundays (C8).

Although some relatives carried out some daily activities with the children, they were not related to the stimulatory activities themselves, and were isolated actions performed when asked by the caregivers so they could carry out other obligations and household chores. Therefore, these caregivers do not receive effective support, nor do they have anyone in the family with whom to share the activities of care for the child with CZS.

Regarding the neuropsychomotor stimulation of the child, it stands out that only one father was mentioned as a participant in the stimulation of the child. In the Brazilian sociocultural context, this is justified by the working activities of the men, which are culturally imposed by society, ratifying their social role of being responsible for financial issues of the household(6).

The stimulatory activities that are developed by the father at home are limited. However, their participation should be valued and encouraged, so they can become actors in the child's development process. Activities such as reading for the child, playing, and showing images should be suggested. For this practice to be carried out, health professionals should involve the fathers in the care of the child, since actions are always targeted and focused towards the maternal figure ${ }^{(13)}$.

Therefore, the participation and involvement of the father contributes for the care of the child and are an essential factor for their emotional balance ${ }^{(4)}$. Additionally, a complicity between the husband/partner and the mother offers the mother of a child with deficiency security and calm, helping them to feel supported and understood ${ }^{(14)}$. That has positive repercussions in the way they can deal with the condition of the child in their daily lives.
Despite the difficulties confronted by the caregivers/ mothers/grandmothers to stimulate the development of the child with CZS at home, some reports were positive, such as the use of some of the devices offered to aid the neuropsychomotor development according to the guidance of the specialized professionals.

I use the plate with color contrasts, the lantern, and the sparkle (shiny pom-pom) [...] when the light is turned off, he starts paying attention (C2).

I do it early in the morning when he wakes up, the stretches [...] so I can put the orthosis, because it's easier to move [...] in the beginning he couldn't open his hand, but after physical therapy, now, he can, so I keep stimulating (C9). I do the stimulation activities the girls (therapists) showed me, stretches, but for the motor part, we bought a baby walker, a transfer [...] / put him there a lot at home, so he can learn to take a step or two. And we have the games [...] (C10).

It can be seen, in the reports of the caregivers, that the equipment acquired, the toys and games, help improving the neuropsychomotor stimulation of the child at home. A study aimed at evaluating the frequency in which the child with cerebral palsy is stimulated and offered support at home has also found that parents offered stimulation using toys or games that allow the free expression and the learning of shapes ${ }^{(15)}$.

Therefore, the relatives of children with deficiency have a fundamental role in the stimulation of their development, if they carefully follow the guidance of the therapists ${ }^{(16)}$. The fact that these professionals, since their first contact, are available to help these caregivers, to listen to them and answer their questions, aids in the creation of a bond between professional and family, and can collaborate to the acceptance and confrontation of the problem, creating a stronger real family-child bond ${ }^{(12)}$.

\section{The continuity of care from the perspective of the health team}

The continuity of the care for children with CZS that is carried out by professionals in the rehabilitation services is essential for the therapies to succeed. However, carrying out the stimulatory activities at home is still a challenge for the caregivers, due to the many different functions they have to perform in the daily care they devote to the child. 
We ask them to continue, so this rehabilitation can show success. [...] it's important for us that they continue it at home. The stretches, for instance: [...] therapy is important, it is, especially if the parents or tutors continue doing it at home (P3).

The family context is seen as one of the most significant protective factors for child development, and as a result, there should be an investment to improve its quality, especially when these environments include children with developmental delays. Certain authors have shown child development to be related to a stimulatory family environment and to the care that is offered to the child. When these aspects are frail, children will be exposed to risk factors and more likely to present developmental delays ${ }^{(8)}$.

Therefore, health professionals must seek to understand the specific features of each family, especially within the family context, and elaborate an assistance that is adequate to the needs of the parents and that is capable of attending them, so that the continuity of the treatment to be carried out by the families becomes viable and appropriate with regards to the care that must be offered, and they manage to be successful in their application of the therapies adopted for their children ${ }^{(7)}$.

Therefore, those involved in the stimulatory activities for the children must be in a collaborative process, that includes the rehabilitation service professionals and the main micro-systems that influence the child's development (family and community), showing an understanding of these contexts as complex, unstable, and intersubjective ${ }^{(17)}$.

It stands out that there are no pediatric nurses in the service in which this research was carried out, which prompts considerations on the need to reevaluate the insertion of this type of professional in rehabilitation services, considering their good therapeutic relations with the family and the fact that they are responsible for the coordination of assistance in different services. Additionally, nurses are paramount in the context of PHC, considering how important they are in the monitoring of the evolution of the child with chronic diseases and their families, so that care can continue at home ${ }^{(5)}$.

Therefore, the work carried out by the health team is essential for the in-house management of the needs generated by neuropsychomotor deficiencies. For that to be a reality, the contribution of parents and caregivers must be improved, so they can interact with the children in a way that establishes early mutuality in communication and affection, preventing emotional disorders and kinesthetic diseases. These are essential strategies in the care for this public ${ }^{(9)}$.

Therefore, the "do it for them" and the "do it with them" is very important for the learning process of the relatives, since showing them how to carry out the actions and asking them to do these actions makes it easier to understand "how to do it" at home, making the tasks more accessible. However, the professionals who participate in this study find that the neuropsychomotor stimulations do not continue at home, since they can tell the children do not evolve in the slightest between consultations. However, they highlight the importance of the multiprofessional work.

Generally we do it first, to show it. The second time we ask her to do it, to make adjustments. [...] But what we see, when they come back the other week, is that they didn't do it (P2).

Well, we always guide them, with the speech therapist, we talk about the acceptance of the child, whether their mastication is good, if they can swallow well. The child needs the formula (special food provided by the government), and when they get it, they improve in physical therapy, they become stronger because of their muscles [...] So, it's a multiprofessional work (P1).

The fact that some caregivers do not continue the stimulatory activities with the child might reflect the lack of professional support, since they do not guide the families according to the actual context of their houses. That is, it is not enough to guide the relative as to the correct way to perform a procedure. In addition to that, the information must be adequate for the context in which the child lives. Otherwise, the treatment will not be successful.

As a result, if the parents are involved in the healthcare process and therapeutic guidance is offered at home, the results in the development of the child will be significant. However, it is important to consider the absence of some factors, such as motivation, communication, expectancies, time, and financial resources, since these affect the continuity of the stimulatory actions by the parents ${ }^{(17)}$. Therefore, communication between professionals and family must be established so that a positive result can be obtained in this process.

To this end, a shared construction of knowledge involving family and professionals, in a perspective based on the Popular Education of Paulo Freire, is a potent tool to generate transformations in reality from considerations of a problem inserted in the context of the search for actions to improve the situation ${ }^{(18)}$.

Therefore, professionals empower parents and provide them with the adequate instruments through well-being, healthy ways of dealing with their life conditions, improvement in access and support to the services needed, and easier offering of better services to the families ${ }^{(4)}$. 
Continuing to offer stimulatory neuropsychomotor activities to the child with CZS at home involves many difficulties due to the routine of care, consultations, and recurring exams to which these children need to be submitted. In addition, some functional limitations of children with CZS are also factors that make things more difficult, as exemplified by the muscular hypertonia that, sometimes, is accompanied by crying spells and convulsions.

I stretch her arm, but her arm is rigid like this, I also stimulate her legs [...], she has a lot of strength. She also has many convulsions, we still didn't find the right medication to stop the convulsions (C4).

I can't do it a lot [...], when I do it she cries. I do what the doctor tells me to do, I stretch like the doctor told me. His little legs too, I stretch, I'm able to, but he cries a lot (C7).

Similarly, other authors found that families find it difficult to deal with the crying, the excessive irritation and rigidity of the child, especially during practical daily activities, such as bathing, cleaning and changing diapers ${ }^{(6)}$. Motor and neurological changes that affect these children irritate them, making other processes more difficult. Moreover, eating disorders, sleep disorders, severe motor deficiencies, visual and auditory abnormalities, and convulsions are presented by these children ${ }^{(19)}$.

Considering these situations, health professionals highlight the impact of this condition in the lives of children with $\mathrm{CZS}$, since it makes it more difficult to carry out stimulatory activities at home. However, they reiterate the need to take advantage of the minimal capacities and abilities the child presents in order to stimulate the child.

\section{[...] about the visual stimulation for the children with severely limited vision, you won't see a fast improvement. [...] Because it's slow, it's slow work. Now, in some children the lesion is minor and we can improve (P5).}

[...] most children with CZS have serious motor problems, we see other associated pathologies, in many of them autism, [...] dysphagia, we see behavioral issues to be highly involved, and that interferes a lot in the prognosis (P3).

[...] muscular retractions, many patients do them, because many of them have associated arthrogryposis [...] and they have serious limitations to their articulations (P4).

These difficulties reported by the health professionals imply directly in the continuity of the neuropsychomotor stimulatory activities at home, considering that most of them have serious motor disorders and the main caregiver often needs someone's aid in order to carry out certain stimulation exercises, but receives no support of the type.

The CZS is associated to neurological alterations, and the type and severity of the sequela varies with each case. According to the Directives for Early Stimulation from the Ministry of Health ${ }^{(9)}$, in situations in which the child presents hypertonia (spasticity), musculoskeletal alterations in the elbow may occur, also in the fists and fingers which stay flexed for too long. The thumb, for instance, is frequently flexed, adducted, and pressed against the palm.

In addition to the aforementioned challenges caregivers have to face for the continuity of stimulatory activities for children with CZS at home, many feelings and emotions are involved in their daily lives, such as the fear of hurting the child while carrying out these activities and the insecurity of not feeling as an active subject in this process.

\section{I do what I can, what I can't, I feel afraid to do, that fear of hurting her, I'm afraid to break something or putting} her little arm in a bad place, we get really afraid (C6).

Because I'm not a professional, that's why l'd like her to be outside, because even receiving stimulation at home she needs professional stimulation (C4).

Reiterating these findings, families of children with microcephaly caused by the Zika virus report to feel fear and insecurity while performing stimulatory activities at home, since they are unsure whether they are doing these activities correctly and leading to positive results in the development of the child, in addition to having doubts as to the motor and intellectual evolution of the child ${ }^{(7)}$.

Therefore, considering the principle of equity, according to which those who need the most should receive the most, these families must also receive assistance from the PHC team, which would allow them to receive continued and integral care, as well as to coordinate the access to the healthcare network ${ }^{(20)}$. As a consequence, we reiterate the need these families have for support, for shared monitoring from health teams at home and/or from the Family Health Support Center (NASF) team, so they can receive guidance and support for family stimulation.

Therefore, the challenges experienced by the caregivers of children with CZS are numerous. Considering this situation, the need becomes clear for trained professionals, specialized health and PHC services, and the government itself, to actively participate and make it possible for this public to continue being cared for. Furthermore, guiding, encouraging and supporting the relatives in the performance of stimulatory 
activities at home is an essential strategy to improve the quality of life of these children.

\section{CONCLUSIONS}

Data shows that the practice of neuropsychomotor stimulatory activities at home is not often carried out due to the overload of requirements of care that falls on the shoulders of the main caregiver for CZS children, which in most cases is the mother. These women face difficulties in their daily lives due to the demands of care of a child with a neurological deficiency, since they have to take the child to many different therapies, medical consultations and routine examinations, in addition to their household chores, conjugal tasks, and to caring for their other children.

Health professionals from the services that are the reference in the care for children with CZS are aware of the overload these women have to deal with. However, they should seek alternatives to encourage and support them in the performance of the stimulatory activities at home, since the home environment is richer in stimulations and more comfortable for the family and the child.

It is also necessary to consider the function of the pediatric nurse in these rehabilitation services, since these professionals are not listed in the directives from the Ministry of Health that address the care for the child with CZS, and were also absent from the one where this research took place. Nonetheless, the nurse is essential in activities of assistance for the children and their families, due to their actions of care, health education, service management, and general actions in the healthcare network as a whole.

We note, as a limitation of this study, the difficulty in interviewing the main caregivers of the child with CZS, considering that they have participated in previous researches and, since they did not learn the results of these previous researches, became resistant to participating in other studies. Additionally, it was difficult to find results of national scientific works on stimulatory activities for the neuropsychomotor development that could be carried out at home.

This study is expected to foment new health researches, as well as public policies that direct strategies to continue the care for children with CZS in the context of their homes, considering the continuous physical growth process of these children, which increases their weight, making it more difficult to transport them to specialized services. These strategies may increase the efficiency of the therapeutic processes for this group, while also diminishing the challenges faced by the caregivers.

\section{REFERENCES}

1. Skråning S, Lindskog BV. The Zika outbreak in Brazil: an unequal burden. Tidsskr Nor Legeforen. 2017;137(22). Norwegian. doi: https://doi.org/10.4045/ tidsskr.17.0655

2. Ministério da Saúde (BR). Monitoramento integrado de alterações no crescimento e desenvolvimento relacionadas à infecção pelo vírus Zika e outras etiologias infecciosas, até a Semana Epidemiológica 52 de 2018. Bol Epidemiol. 2019 [citado 2019 jun 12];50(8):1-8. Disponível em: http://portalarquivos2. saude.gov.br/images/pdf/2019/marco/22/2019-001.pdf

3. Rocha NACF, Campos AC, Rocha FCF, Silva FPS. Microcephaly and Zika virus: neuroradiological aspects, clinical findings and a proposed framework for early evaluation of child development. Infant Behav Dev. 2017;49:70-82. doi: https:// doi.org/10.1016/j.infbeh.2017.07.002

4. Costa ES, Bonfim EG, Magalhães RDLB, Viana LMM. Vivências de mães de filhos com microcefalia. Rev Rene. 2018;19:e3453. doi: https://doi. org/10.15253/2175-6783.2018193453

5. Geense WW, van Gaal BGI, Knoll JL, Cornelissen EAM, van Achterberg T. The support needs of parents having a child with a chronic kidney disease: a focus group study. Child Care Health Dev. 2017;43(6):831-8. doi: https://doi. org/10.1111/cch.12476

6. Pinto RNM, Torquato IMB, Collet N, Reichert APDS, Souza Neto VLD, Saraiva AM. Infantile autism: impact of diagnosis and repercussions in family relationships. Rev Gaúcha Enferm. 2016;37(3):e61572. doi: https://doi. org/10.1590/1983-1447.2016.03.61572

7. Sá FE, Andrade MMG, Nogueira EMC, Lopes JSM, Silva APÉP, Assis AMV. Parental needs in the care for children with Zika virus-induced microcephaly. Rev Bras Promoc Saúde. 2017;30(4):1-10. doi: https://doi. org/10.5020/18061230.2017.6629

8. Correa W, Minetto MF, Crepaldi MA. Família como promotora do desenvolvimento de crianças que apresentam atrasos. Pensando Fam. 2018 [citado 2019 jun 12];22(1):44-58. Disponível em: http://pepsic.bvsalud.org/ scielo.php?script=sci_arttext\&pid=\$1679-494X2018000100005

9. Ministério da Saúde (BR). Secretaria de Atenção à Saúde. Diretrizes de estimulação precoce: crianças de zero a 3 anos com atraso no desenvolvimento neuropsicomotor decorrente de microcefalia. Brasília (DF): Ministério da Saúde; 2016 [citado2019 maio 10]. Disponível em: http://bvsms.saude.gov.br/bvs/ publicacoes/diretrizes_estimulacao_criancas_0a3anos_neuropsicomotor.pdf

10. Minayo MCS. Amostragem e saturação em pesquisa qualitativa: consensos e controvérsias. Rev Pesq Qual. 2017 [citado 2019 jun 10];5(7):1-12. Disponível em: https://editora.sepq.org.br/index.php/rpq/article/view/82/59

11. Minayo MCS. 0 desafio do conhecimento: pesquisa qualitativa em saúde. 11. ed. São Paulo: Hucitec; 2014.

12. Almeida TCSD, Ruedell AM, Nobre JRDS, Tavares KO. Paralisia cerebral: impacto no cotidiano familiar. Rev Bras Ciênc Saúde. 2015;19(3):171-8. doi: https://doi. org/10.4034/RBCS.2015.19.03.01

13. Jeong J, McCoy DC, Yousafzai AK, Salhi C, Fink G. Paternal stimulation and early child development in low- and middle-income countries. Pediatrics. 2016;38(4):e20161357. doi: https://doi.org/10.1542/peds.2016-1357

14. Pereira EL, Bezerra JC, Brant JL, Araújo WND, Santos LMP. Profile of demand and Continuous Cash Benefits (BCP) granted to children diagnosed with microcephaly in Brazil. Ciênc Saúde Coletiva. 2017;22(11):3557-66. doi: https://doi.org/10.1590/1413-812320172211.22182017 
15. Azevedo TL, Della Barba PCS. Avaliação da estimulação e apoio no ambiente familiar oferecido à criança com paralisia cerebral. Rev Ter Ocup. 2017;28(2):198205. doi: https://doi.org/10.11606/issn.2238-6149.v28i2p198-205

16. Belizário M, Chita PHB, Rocha LB. A importância da família no brincar da criança paralisada cerebral quadriplégica espástica. Multitemas. 2016 [citado 2019 maio 10];25:25-30. Disponível em: http://www.multitemas.ucdb.br/article/ view/837

17. Phoenix M, Jack SM, Rosenbaum PL, Missiuna C. A grounded theory of parents' attendance, participation and engagement in children's developmental rehabilitation services: Part 2. The journey to child health and happiness. Disabil Rehabil. 2019 Jan 23:1-10. doi: https://doi.org/10.1080/09638288.2018.1555 618 [Epub ahead of print]
18. Sevalho $G$. The concept of vulnerability and health education based on the teory laid out by Paulo Freire. Interface (Botucatu). 2018 Jan-Mar 22(64):177-88. Portuguese. doi: https://doi.org/10.1590/1807-57622016.0822

19. Satterfield-Nash A, Kotzky K, Allen J, Bertolli J, Moore CA, Pereira I0, et al. Health and development at age 19-24 months of 19 children who were born with microcephaly and laboratory evidence of congenital Zika virus infection during the 2015 Zika virus outbreak - Brazil, 2017. MMWR Morb Mortal Wkly Rep. 2017;66(49):1347-1351. doi: https://doi.org/10.15585/mmwr. mm6649a2

20. Enlow E, Passarella M, Lorch SA. Continuity of care in infancy and early childhood health outcomes. Pediatrics. 2017,140(1):e20170339. doi: https:// doi.org/10.1542/peds.2017-0339

\section{- Corresponding author:}

Cora Coralina dos Santos Junqueira

E-mail:coracoralina33@gmail.com

\section{Editor-in-chief:}

Maria da Graça Oliveira Crossetti 